\title{
INCIDENCE OF TUBERCLE BACILLI IN MILK AND SOME MILK PRODUCTS IN BENI- SUEF CITY, EGYPT
}

\author{
SAADIA H ELSHINAWY ${ }^{1}$; MOHAMED M.A. ZEINHOM ${ }^{1}$; RIAD E.M. ${ }^{2}$ and WALAA ASHOUR ${ }^{3}$ \\ ${ }^{1}$ Food Hygiene and Control Department, Faculty of Veterinary Medicine, Beni-Suef University, Beni-Suef 62512, Egypt. \\ ${ }^{2}$ Bacteriology Department, Animal Health Research Institute, Egypt. \\ ${ }^{3}$ Animal Health Research Institute, Beni-Suef Branch, Beni-Suef, Egypt.
}

Received: 28 March 2016; Accepted: 12 April 2016

\begin{abstract}
Although milk and milk products are important components of a healthy diet, if consumed unpasteurized, they also can present a health hazard due to possible contamination with pathogenic bacteria. Bovine tuberculosis (BT) is a classic example of zoonotic milk borne diseases transmitted from cattle to human. To validate this hypothesis, the current study was designed to record the prevalence of mycobacterium species in raw milk and some dairy products. Two hundred and forty two samples; (100) raw milk, (77) fresh cream and (65) kareish cheese were collected randomly from different areas in Beni-Suef city (Egypt). Mycobacterium bovis was detected in $4.95 \%$ of samples by using culturing method while the incidence by using Polymerase Chain Reaction (PCR) was $7.02 \%$ of the examined samples. These evidences reinforces the need to optimize quality programs of dairy products to intensify the sanitary inspection of these products and the necessity of further studies on the presence of mycobacterium spp. in milk and its products.
\end{abstract}

Key words: Mycobacterium spp. Milk, Milk products, Public health.

\section{INTRODUCTION}

Milk is the most important part of the human diet which is used in different forms as food and it is not only nature's food for a newly born infants, but also a source for a whole range of dairy products consumed by mankind. Approximately $50 \%$ of the milk produced from the dairy animals is consumed fresh, boiled or in pasteurized form. It plays a prominent role in meeting the essential human dietary requirements (protein, lactose, fat, mineral and vitamins) (Dairy Facts, 2003). The importance of the Milk intake during childhood and adolescence of dietary calcium which in the United States is derived largely from milk and dairy products to the risk of osteoporotic fractures in later life is generally assumed to be fact (Tucker, 2003).

Kareish cheese is one of soft cheeses which are most popular in Egypt and Arabian countries owing to its high protein, low fat and reasonable price. It is an acid coagulated fresh cheese, made from skim milk with soft composition white curd and slightly salty (Francois et al., 2004). Kareish cheese is considered one of the most food products rich in calcium and

Corresponding author: Dr. MOHAMED M.A. ZEINHOM

E-mail address: m.zeinhom@vet.bsu.edu.eg, m ma3roof@yahoo.com

Present address: Food Hygiene and Control Department, Faculty of Veterinary Medicine, Beni-Suef University, Beni-Suef 62512, Egypt. phosphorus. These elements are essential for bones and teeth formation, it is also rich in sodium and potassium, which play an important role in the formation of body liquids and muscles (Mahmoud et al., 2013).

Cream is the milk product comparatively rich in fats separated from milk either by gravity or by centrifugal separator. Microbiological analysis of cream for specific pathogens isn't considered justified and testing is restricted to potential spoilage microorganisms. (Ma and Barbano, 2000).

However, these nutrients can also serve as substrates for pathogenic microorganisms. The traditional consumption of homemade dairy products, and especially cheeses, that are composed of non-heattreated milk pose a serious risk to public health to avoid tuberculosis (TB) infection (Di Pinto et al., 2006). Milk is considered a potential vehicle for transmission of some organisms which may be pathogenic for humans. External interferences in the temperature of pasteurization, extreme bacterial load contamination during milking and bottling processes may favor the survival of some species of bacteria including pathogenic or facultative pathogenic mycobacteria (Donaghy et al., 2007).

Mycobacterium bovis is the etiologic agent of TB in cows and humans. Both cows and humans can serve as reservoirs. Humans can be infected by the consumption of unpasteurized milk. This route of transmission can lead to the development of extra- 
pulmonary TB. M. bovis affects livestock species of economic significance such as cattle (the true hosts), causing animal health problem and serious economic losses to farmers worldwide including a reduction of (10-20\%) in milk production and weight (Lilenbaum et al., 2001).

Mycobacterium bovis are highly able to survive in bovine milk and other dairy products. These microbes can be found in the form of viable bacilli in cream cheese and yogurt produced from raw milk for over 14 days and in butter for over 100 days (De La RuaDomenech, 2006). Recently, the presence of these opportunistic, pathogenic bacteria in milk has emerged as a public-health concern, especially among individuals who consume raw milk and related dairy products (Chye et al., 2004).

Tuberculosis (TB) is the leading cause of death in the world from a bacterial infectious disease. The disease affects 1.8 billion people/year which is equal to onethird of the entire world populations. Bovine tuberculosis is a disease of zoonotic concern, especially in countries with no control programs in livestock and where routine pasteurization of milk is not practiced (Roug et al., 2014), and it was the cause of approximately $6 \%$ total human deaths due to BTB in $1930-1940$ (Vordermeier et al., 2001). It is noteworthy to mention that more than 30 million cases of TB have been registered across the world at the beginning of the 21st century (Hosek et al., 2006).

M. bovis in cattle may involve in some cases udder lesions and the bacilli excreted in milk or sheded in their milk due to septicemic and cutaneous infection. In both instances sufficient levels of mycobacteria can be excreted from a single cow to make 100 gallons of previously non contaminated milk infectious for infants. Raw milk and milk products are considered the main source of primary tuberculosis in children and infants (Connell et al., 2006). Tuberculosis in humans is caused by either M. bovis or M. tuberculosis. It is possible to extract surviving ancient mycobacterial DNA and amplify it by PCR. Using this technique, a laboratory performed a study of five individuals from Aymyrlyg, South Siberia, to determine the type of tuberculosis infection (Michel, 2007).

Pasteurization of milk and dairy products dropped the Bovine tuberculosis (BTB) rate drastically. Although, in developed countries, bovine tuberculosis has been considered under control, the re-emergence of the disease has been reported (Thoen et al., 2006; Rowe and Donaghy, 2008).

The aim of this work was to present a credible and objective study that would be understandable to those who drink fresh unprocessed milk from our local farmers and should be afraid of becoming infected with bovine tuberculosis. So, this study was performed considering: (1) Investigation of dairy shops, markets and farmer's houses for detection of the prevalence of tubercle bacilli in collected samples;(2) Isolation of Mycobacterium bovis from the samples; (3)Confirmation of isolated strains of Mycobacterium Spp. by PCR; (4) Discussion of the public health hazard of the micro-organism

\section{MATERIALS AND METHODS}

Collection of samples: Two hundred and forty two samples (100 raw milk, 77 fresh cream and 65 kareish cheese samples), were collected randomly from dairy shops, markets and farmer's animals at different localities in Beni-Suef city, Egypt. All samples were transferred to the laboratory in an insulated ice box for bacteriological examination.

Preparation of samples (APHA, 1992): For milk samples, $100 \mathrm{ml}$ of well mixed milk samples were centrifuged for $30 \mathrm{~min}$ at $3000 \mathrm{rpm}$ then, freshly used or stored at $-20 \mathrm{C}^{\circ}$. For cream and kareich cheese samples, Ten grams of each sample were homogenized in a sterile polyethylene bag with equal volume of sterile sodium citrate $2 \%$ solution at $40^{\circ} \mathrm{C}$.

Detection of heat treated milk using Storch's test (Lampert, 1975): To $10 \mathrm{ml}$ of well mixed sample which collected from dairy shops, 2 drops of diluted Hydrogen peroxide $0.2 \%$ were added before the addition of 2 drops of freshly prepared aqueous solution of paraphenylene diamine (2\%). The contents were thoroughly mixed. Indigo blue color produced immediately indicates raw milk, and the light blue indicates intermediate or mixed milk, while in milk subjected to heat treatment light brown or no color is noticed.

Isolation and identification of Mycobacterium bovis: $100 \mathrm{ml}$ of well mixed samples were transferred into sterile centrifuge tubes spun for 30 minutes at $3000 \mathrm{rpm}$. The cream and milk are poured off and the remaining sediment is mixed thoroughly with an equal volume of $6 \% \mathrm{HCL}$ and incubated at $37^{\circ} \mathrm{C}$ for $30 \mathrm{~min}$. The mixture is centrifuged for $30 \mathrm{~min}$ at 3000 rpm., the supernatant fluid is poured off and the sediment is neutralized with $4 \%$ sterile $\mathrm{NaOH}$ solution using phenol red as an indicator (the change in color from orange to pink indicates correct neutralization), then, re-centrifuged for further examinations. Three to Five drops of the decontaminated sediment were inoculated in 6 screw capped bottles each two containing (Dorset egg media, Lowenstein- Jensen media and Middle brook 7H10 agar media). Inoculated tubes were sealed and incubated at $37^{\circ} \mathrm{C}$ for at least 60 days with daily, and then weekly observation ( Except for Middle brook 7 H10 agar media was incubated for maximum 24 days) (Corner et al., 1995).

The isolates were subjected to further microscopic (Kent and Kubica, 1985) and biochemical 
identification (Niacin, nitrate reduction, hydrolysis of tween 80, catalase, iron uptake and urease tests), as described by (Vestal, 1975; Kent and Kubica, 1985).

\section{Extraction of DNA (Wards et al., 1995)}

DNA extraction method for original samples: (According to thermo scientific, GeneJET Genomic purification kit \#K0721, \#0722). Four hundred $\mu 1$ of lysis solution was added and $20 \mu \mathrm{l}$ of proteinase $\mathrm{K}$ to $200 \mu \mathrm{l}$ of sample, mixed thoroughly by vortexing or pipetting to obtain a uniform suspension. The sample was incubated at $56^{\circ} \mathrm{C}$ while vortexing occasionally or using a shaking water bath, rock platform or thermos mixer until the cells are completely lysed (10 min). About $200 \mu \mathrm{l}$ of ethanol (96-100\%) was added and mixed by vortexing or pipetting. The prepared lysate was transferred to Gene JET Genomic purification column inserted in a collection tube. Then centrifugation for $1 \mathrm{~min}$ at $6000 \times \mathrm{g}$. The collection tube was discarded containing the flowthrough solution. The Gene JET Genomic purification column was placed into a new $2 \mathrm{ml}$ collection tube. $500 \mu$ l of wash buffer I (with ethanol added) was added and Centrifuged for $1 \mathrm{~min}$. at $8000 \times \mathrm{g}$. The500 $\mu \mathrm{l}$ of wash buffer flow was discarded through and the purification column was placed back into the collection tube. Then $500 \mu \mathrm{l}$ of wash buffer $\|$ (with ethanol added) was added to the Gene JET Genomic purification column. Centrifugation for $3 \mathrm{~min}$ at maximum speed $(\geq 1200 \times \mathrm{g})$. The collection tube was discarded containing the flow- through solution. The GeneJET Genomic purification column was placed into a sterile $1.5 \mathrm{ml}$ microcentrifuge tube. $200 \mu \mathrm{l}$ of Elution buffer was added to the center of the GeneJET Genomic purification column membrane to elute genomic DNA. Incubation for $2 \mathrm{~min}$ at room temperature and Centrifugation for $1 \mathrm{~min}$ at $8000 \times \mathrm{g}$. The purification column was discarded. The purified DNA was used immediately in downstream application or store at $-20^{\circ} \mathrm{C}$.

Extraction of DNA from isolated microorganism: (According to thermo scientific, GeneJET Genomic purification kit \#K0721, \#0722). Before starting; prepare bacteria lysis buffer. Twenty $\mathrm{mM}$ Tris-Hcl, $\mathrm{pH} 8.0,2 \mathrm{mM}$ EDTA, 1.2\% Triton X-100, add lysozyme to $20 \mathrm{mg} / \mathrm{ml}$ immediately before use. Adequate number of bacterial cells were harvested in a 1.5 or $2 \mathrm{ml}$ microcentrifuge tube by centrifugation for $10 \mathrm{~min}$ at $5000 \times \mathrm{g}$. Discard the supernatant and suspend the pellet in $180 \mu \mathrm{l}$ of the prepared bacterial lysis buffer. $200 \mu \mathrm{l}$ of lysis solution was added and 20 $\mu \mathrm{l}$ of proteinase $\mathrm{K}$ to $200 \mu \mathrm{l}$ of isolated microorganism, and mixed thoroughly by vortexing or pipetting to obtain a uniform suspension. The suspected microorganism was incubated at $56^{\circ} \mathrm{c}$ while vortexing occasionally or using a shaking water bath, rock platform or thermo mixer until the cells are completely lysed (10min.). $20 \mu \mathrm{l}$ of RNase A solution was added, mixed by vortexing and incubation of the mixture for $10 \mathrm{~min}$. at room temperature. $400 \mu \mathrm{l}$ of ethanol (96-100\%) was added and mixed by vortexing or pipetting. The prepared lysate was transferred into Gene JET Genomic DNA purification column inserted in a collection tube. The column was centrifuged for $1 \mathrm{~min}$. at $6000 \times \mathrm{g}$. The collection tube was discarded containing the flow-through solution. The Gene JET Genomic purification column was placed into a new $2 \mathrm{ml}$ collection tube. $500 \mu \mathrm{l}$ of wash buffer I (with ethanol added) was added. Centrifugation for $1 \mathrm{~min}$ at $8000 \times \mathrm{g}$, then discarding the flow through and the purification column was placed back into the collection tube. $500 \mu \mathrm{l}$ of wash buffer II (with ethanol added) was added to the Gene JET Genomic purification column, and centrifugation for $3 \mathrm{~min}$. at maximum speed $(\geq 1200 \times \mathrm{g})$, then discarding the collection tube containing flowthrough solution. The Gene JET Genomic purification column was placed into a sterile $1.5 \mathrm{ml}$ microcentrifuge tube. $200 \mu \mathrm{l}$ of Elution buffer was added to the center of the Gene JET Genomic purification column membrane to elute genomic DNA. Incubate for $2 \mathrm{~min}$ at room temperature and centrifuge for 1 min. at $8000 \times \mathrm{g}$. The purification column was discarded. The purified DNA was used immediately in downstream application or store at $-20^{\circ} \mathrm{c}$.

Detection of $M$. tuberculosis complex (Ben Kahla et al., 2011): Real time PCR was performed according to the kit obtained from biovision ${ }^{\circledR}$ Real time PCR for samples was performed by using MTplex dtec-RT - qPCR Test designed for detection of the Mycobacterium bovis. Extracted DNA from the suspected samples was subjected to RT-PCR. The primers and TaqMan probe target a sequence conserved for $M$. bovis. The PCR was performed in a total of $20 \mu \mathrm{l}$, which contained $10 \mu \mathrm{l}$ Hot Start-Mix qPCR $2 \times, 1 \mu$ MTplex dtec-qPCR-mix, $4 \mu$ l DNase/ RNase free water and $5 \mu \mathrm{l}$ DNA sample. The reaction conditions consisted of one cycle at $95^{\circ} \mathrm{C}$ for $5 \mathrm{~min}$ followed by 45 cycles at $95^{\circ} \mathrm{C}$ for $30 \mathrm{sec}$ and $60^{\circ} \mathrm{C}$ for $60 \mathrm{sec}$ for hybridization, extension and data collection. the reaction was run in Applied Biosystem Step One Real Time PCR System and FAM fluorogenic signal was collected and the cycle threshold of the reactions was detected by Step One ${ }^{\text {TM }}$ software version 2.2.2 (Life Technology). Sequences for primers used in this study are as follow; forwaed JB21 (TCGTCCGCTGATGCAAGTGC) and reverse JB22 (CGTCCGCTGACCTCAAGAAAG) Primer amplifying a $500 \mathrm{bp}$ genomic fragment specific for M. bovis (Mumtaz et al., 2008). 


\section{RESULTS}

\section{Results of conventional culture technique:}

Table 1: Incidence of $M$. bovis in the examined samples by conventional culture technique.

\begin{tabular}{cccc}
\hline Samples & No of tested samples & Positive samples & \% of Positive samples \\
\hline Raw milk & 100 & 6 & $6.00 \%$ \\
Cream & 77 & 2 & $2.59 \%$ \\
Kareish cheese & 65 & 4 & $6.15 \%$ \\
\hline Total & 242 & 12 & $4.95 \%$ \\
\hline
\end{tabular}

Table 2: Incidence of M.bovis in the examined samples by using real time PCR assay.

\begin{tabular}{cccc}
\hline Samples & No of tested samples & Positive samples & \% of positive samples \\
\hline Raw milk & 100 & 8 & 8 \\
\hline Cream & 77 & 3 & 3.89 \\
\hline Kareish cheese & 65 & 6 & 9.23 \\
\hline Total & 242 & 17 & 7.02 \\
\hline
\end{tabular}

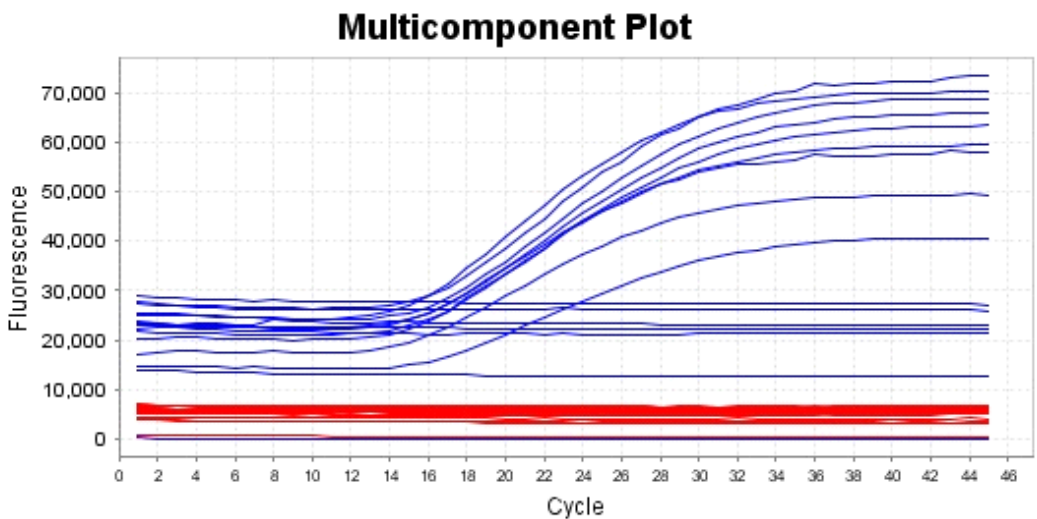

A $\quad$ B $\square$ C D D $\square$ E

Fig.1: The amplification plot of suspected milk samples. Analysis for the amplification plot in its linear form: Eight samples at cycle 14 and one control positive sample, six negative samples. The used reference dye is (FAM). The run is for 45 cycles.

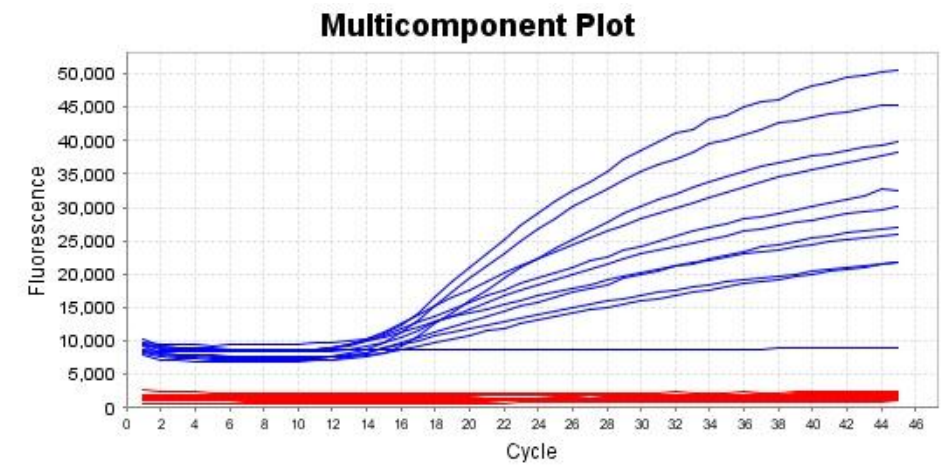

FAM ROX

Fig.2: The amplification plot of suspected milk products samples. Analysis for the amplification plot in its linear form: Nine positive samples at cycle 14 and one control positive sample, one negative sample. The used reference dye is (FAM). The run is for 45 cycles. 
Table 3: Comparison between results of culture technique and PCR assay.

\begin{tabular}{cccccc}
\hline \multirow{2}{*}{ Samples } & No of tested samples & \multicolumn{2}{c}{ Culture technique } & \multicolumn{2}{c}{ RT-PCT } \\
\cline { 3 - 6 } & & \multicolumn{2}{c}{ Positive } & \multicolumn{2}{c}{ Positive } \\
\hline & & No & $\%$ & No & 8 \\
\hline Raw milk & 100 & 6 & 6 & 3 & 3.89 \\
\hline Cream & 77 & 2 & 2.59 & 6 & 9.23 \\
\hline Kareish cheese & 65 & 4 & 6.15 & 17 & 7.02 \\
\hline Total & 242 & 12 & 4.95 & & 3 \\
\hline
\end{tabular}

\section{DISCUSSION}

Foodborne diseases are a public health problem worldwide. The consumption of contaminated raw milk or dairy products has been recognized as a major cause of transmission of bovine tuberculosis to humans. Tuberculosis is considered one of the highest mortality rates worldwide among the infectious diseases. Eighteen people are affected with TB every minute globally and three of them die per minute (WHO, 2013). Results recorded in Table (1) revealed that out of 242 examined milk and milk products samples, 12 samples were positive for Mycobacterium bovis with a percentage of $4.95 \%$ by microscopical examination and all positive samples were harbored the acid fast bacilli. Regarding to conventional culture technique on raw milk samples (6 out of 100), Cream samples ( 2 out of 77) and Kareish cheese samples (4 out of 65) were positive to $M$. bovis with a percentages of $6,2.59$ and $6.15 \%$, respectively. These findings prove that $M$. bovis is a good survivor in milk, cheese and cream (Van Brandt et al., 2011).

Similar results were detected in Egypt by Wahba et al. (2013) who found that $6 \%$ of the examined milk samples were microscopically positive to $M$. bovis and nearly similar results were obtained by $\mathrm{Gad}$ et al. (2000) with a percentage of 5.6\%.

On the other hands, lower results in Egypt, were obtained by Hassanain et al. (2009) who revealed that $4.35 \%$ of the collected 23 bovine milk samples were positive for $M$. bovis using culture technique, as well as Wahba et al. (2013) in a study conducted on market milk samples, they reported that out of 50 examined milk samples there was $1(2 \%)$ positive by culture. In Iraq, Al- Saqur et al. (2009) detected 3 $(4.4 \%)$ positive samples out of 68 examined milk samples by microscopical examination. In Nigeria, Ofukwu et al. (2008) found that 4 (1.4\%) of the 285 freshly drawn milk samples were positive by culture and microscopical examination in some Makurdi markets. Additionally, lower results were obtained by Centers for Disease Control and Prevention (2005) which mentioned that investigation in New York
City reported that $1 \%$ of culture-positive tuberculosis cases in milk in this area were due to $M$. bovis.

Higher results for culturing technique were determined by Abou-Eisha et al. (2002) in Egypt who detected that $2(7.7 \%)$ of the 26 milk samples were positive for M. bovis. Also Franco et al. (2013) and Pardo et al. (2001) in Brazil were able to isolated M. bovis from milk samples in percentages of 8 and $10 \%$, respectively. Furthermore, higher results were obtained by Hamid et al. (2003) in Pakistan who conducted a study at Lahore and isolated $M$. bovis from milk samples of four cows out of $16(25 \%)$ with confirmed bovine tuberculosis. In Iraq, Al- Saqur et al. (2009) conducted a study on 68 raw milk samples and found that the positive rates for culture were 7 $(10.2 \%)$.

In addition to that LoBue et al. (2004) in San Diego County, CA, found that 129 out of 1,931 (6.7\%) samples of soft fresh cheese originated in Mexico cultured for mycobacterium were $M$. bovis. These results were nearly similar to our findings for Kareish cheese, while lower results for cheese samples were reported by Leite et al. (2003) who examined a total of 203 samples and proved that $10(4.9 \%)$ were positive for bacteria belonging to the genus Mycobacterium, with one isolate being identified as M. bovis.

At the same time, De La Rua-Domenech (2006) found that microorganisms of the Mycobacterium genus, such as Mycobacterium bovis, are highly able to survive in bovine milk and other dairy products. The author mentioned that these microbes could be isolated from cream, cheese and yogurt produced from raw milk for over 14 days and in butter for over 100 days and mentioned that there are no validated laboratory methods that allow the certification of such untreated milk or dairy products as "free of viable mycobacteria". He found that although $M$. bovis does not multiply in milk or does so very slowly, the large number of mycobacteria that are secreted into the milk of one animal with tuberculous mastitis is generally sufficient to render the homogenized milk from 100 lactating cows. 
All samples of the present study were tested and confirmed by using real time PCR. The obtained results of molecular detection of Mycobacterium bovis were shown in Table (2); Fig $1 \& 2$ revealed that, 8 out of 100 raw milk samples were positive with apercentage of $8 \%$.

The detection of mycobacterium bovis contamination in 65 kareish cheese and 77 cream samples by real time PCR revealed that 6 kareish cheese samples were positive and harbored mycobacterium bovis as well as 3 cream positive samples.

The use of raw milk in the production of cheese and other dairy products is considered a potential public health risk associated with tuberculous cattle, as viable mycobacteria (including $M$. bovis) have been found to survive in mature unpasteurized cheeses (Nasr et al., 2014). M. bovis is very resistant to chemical disinfectants, including acids and alkalis, and is considered less likely than other pathogens to be affected by the pH of the cheese (Spahr and Schafroth, 2001).

Lower results were recorded by El-Gedawy et al. (2014) who examined one hundred bulk tank milk samples collected from three dairy farms at Sharkia Province, Egypt, for detection of M. bovis by PCR, and found only apercentage of $1 \%$. Also, lower results were obtained by Silaigwana et al. (2012) who detected $11(5.5 \%)$ positive milk samples. On contrast, Ereqat et al. (2013) failed to detect any positive cases among 30 examined milk samples.

Higher results were obtained by Leite et al. (2003), who conduct a study on 128 bovine milk samples from retail markets in the State Sâo Paulo, out of them there were $23(18 \%)$ positive milk samples by PCR. Also, Ogundeji et al. (2015) was able to isolate $9(18 \%)$ samples as a positive to Mycobacterium out of the 50 milk samples with the PCR method. 1 (2\%) out of the 9 positive milk samples was found to be Mycobacterium tuberculosis while the remaining 8 (16\%) were detected to be Mycobacterium bovis after using the digestion enzyme.

Regarding to the results of Kareish cheese, PereiraSuarez et al. (2014) examined 95 samples of fresh cheese that were obtained from municipal markets in the state of Hidalgo, Mexico. They reported that $M$. tuberculosis complex DNA was detected by nestedPCR amplification of a fragment of the mpb70 gene in six samples, four of which were obtained from regions with enzootic bovine tuberculosis. They concluded that cheeses prepared from raw milk and contaminated with $M$. bovis are being sold and consumed by humans, which may cause tuberculosis.
Data given in Table (3) showed the comparison between results of culture technique and PCR assay for detection of bovine tuberculosis where the results revealed that out of 242 samples only 12 samples were positive by culture technique with percentage of $4.95 \%$, while the same samples revealed 17 positive samples by RT-PCR with a percentage reached $7.02 \%$, Tipu et al. (2012) analyzed milk samples through conventional (culture) and modern (PCR) methods in dairy cattle in and around Lahore. During 10 months (May 2007 to February 2008) period, out of 1000 samples, $454(45.4 \%)$ were positive with PCR, 69 samples $(15 \%)$ were positive for direct acid fast staining and 31 samples (7\%) were positive with isolation and identification of $M$. bovis. and confirmed that the presence of M. bovis in raw milk samples is an enormous health risk factor for milk handlers and end consumers.

Liebana et al. (1995) mentioned that the PCR technique is much faster than the culture methods, as it reduces the time for diagnosis from several months to 2 days. It also provides for the detection of $M$. bovis when rapidly growing Mycobacterium spp. are present in the sample and may be able to detect the presence of $M$. bovis in samples even when organisms have become non-viable. Additionally, Al- Saqur et al. (2009) proved that only three bacilli in milk samples sufficient to be detected by real time PCR. They recorded 7 (10.3\%) were positive by real time PCR which are higher than that obtained by culture technique and attributed that as the PCR give. high sensitivity and specificity for the Mycobacterium This leading to the fact that real time PCR is more accurate and faster than conventional method for TB diagnosis. As early diagnosis of TB disease is crucial in initiating treatment and interrupting the strain transmission, rapid diagnosis will prevent the development of drug resistant $M$. tuberculosis.

So, the rapid detection of mycobacterium spp. is essential and important especially toward the public health issue.

\section{CONCLUSION}

Milk and Milk products is subjected to many risks of contamination by TB due to lake of TB controlling measures in farms, absence of pasteurization and sanitary methods of processing and distribution, Products from un-pasteurized cow's milk have been associated with certain infectious diseases including M. bovis. So, M. bovis can be prohibited by pasteurization of milk before consumption and during manufacturing of dairy products and culling of infected cattle herds. 


\section{REFERENCES}

Abou-Eisha, A.M.; El-Attar, A.A.; El-Sheary, M.N. (2002): Bovine and atypical mycobacterial infections of cattle and buffaloes in Port Said Province, Egypt. Vet. Med. J., 47(93): 152162.

Al-Saqur, I.M.; AL-Thwani, A.N. and Al-Attar, I.M. (2009): Detection of Mycobacteria spp. in cow's milk using conventional methods and PCR. Iraqi Journal of Veterinary Sciences, Vol. 23, Supplement $\|:$ 259-262. Proceeding of the $5^{\text {th }}$ Scientific Conference, College of Veterinary Medicine, University of Mosul.

APHA; American Public Health Association (1992): Standard Methods for the Examination of Dairy Products. I N C., $16^{\text {th }}$ Ed., New York.

Ben kahla, Boschiroli M.L.; Souissi, F.; Cherif, N.; Benzarti, M.; Boukadida, J. and Hammami, S. (2011): Isolation and molecular characterization of Mycobacterium bovis from raw milk in Tunisia. Afr. Hlth. Sci., 11(51): 52-55.

Centers for Disease Control and Prevention (2005): Human tuberculosis caused by Mycobacterium bovis - New York City, 20012004. Morb. Mortal. Wkly. Rep., 54: 605608.

Chye, F.Y.; Abdullah, A. and Ayob, M.K. (2004): Bacteriological quality and safety of raw milk in Malaysia. Food Microbiol., 21: 535-541.

Connell, T.G.; Curtis, N.; Ranganathan, S.C. and Buttery, J.P. (2006): Performance of a whole blood interferon gamma assay for detecting latent infection with mycobacterium tuberculosis in children. Thorax 61(7): 616620.

Corner, L.A.; Trajstman, A.C. and Lund, K.L. (1995): Determination of the optimum concentration of decontamination for the primary isolation of Mycobacterium bovis. New Zealand Veterinary Journal, 43(1): 129133.

Dairy facts (2003): Edition. Nutrition information, 13. International dairy foods Association. Washingaton, DC. 12.

De La Rua-Domenech, R. (2006): Human Mycobacterium bovis infection in the United Kingdom: incidence, risks, control measures, and review of the zoonotic aspects of bovine tuberculosis. Tuberculosis 86 : 77-109.

Di Pinto, A.; Ciccarese, G.; Forte, T.V.; Bijo, B.; Shehu, F. and Tantillo, G. (2006): Detection of mycobacterium tuberculosis complex in milk using polymerase chain reaction (PCR). Food Control.17:776-780.

Donaghy, J.A.; Linton, M.; Patterson, M.F. and Rowe, M.T. (2007): Effect of high pressure and pasteurization on Mycobacterium avium ssp paratuberculosis in milk. Lett. Appl. Microbiol., 45(2):154-159.

El-Gedawy, A. A.; Ahmed, H. A. and Awadallah, M.A.I. (2014): Occurrence and molecular characterization of some zoonotic bacteria in bovine milk, milking equipments and humans in dairy farms, Sharkia, Egypt. Int. Food Res. J., 21(5): 1813-1823.

Ereqat, S.; Nasereddin, A.; Levine, H.; Azmi, K.; AlJawabreh, A.; Greenblatt, Ch.; Abdeeb, Z. and Bar- Gal, G. (2013): First time detection of Mycobacterium bovis in livestock tissues and milk in the west Bank, Palestinian Territories. PLoS. Negl. Trop. Dis., 7 (9): e2417.

Franco, M.M.J.; Paes, A.C.; Ribeiro, M.G.; Pantoja, J.C.F.; Santos, A.C.B.; Miyata, M.; Leite, C.Q.F.; Motta, R.G. and Listoni, F.J.P. (2013): Occurrence of mycobacteria in bovine milk samples from both individual and collective bulk tanks at farms and informal markets in the southeast region of Sao Paulo, Brazil. BMC Vet. Res., 9(85): 1-8.

Francois, Z.N.; Ahmed, N.; Felicite, M.T. and ElSoda, M. (2004): Effect of ropy and capsular exopolysaccharides producing strain of Lactobacillus plantarum162 RM on characteristics and functionality of fermented milk and soft Kareish type cheese. Afr. J. Biotechnol., 3 (10): 512-518.

Gad, E.W.A.; EL-Abeedy, A.; Mettias, K.N. and Manal, A. (2000): The present state and public health importance of tuberculosis of bovine udder. J. Egypt. Vet. Med. Ass., 60(6): 189194.

Hamid, H.; Das, P. and Suleman, A. (2003): Bovine tuberculosis in Dairy Animals at Lahore, Threat to the Public Health. Published online on January 23, 2003, in VETSCAN.COM, an online magazine.

Hassanain, N.; Hassanain, M.; Soliman, Y.A.; Ghazy, A. and Ghazy, Y.A. (2009): Bovine tuberculosis in dairy cattle farm as a threat to public health. Afr. J. Microbiol. Res., 3(8): 446-450.

Hosek, J.; Svastova, P.; Moravkova, M.; Pavlik, I. and Bartos, M. (2006): Methods of mycobacterial DNA isolation from different biological material: a review. Veterinarni Medicina, 51(5): 180-192.

Kent, P.T. and Kubica, G.P. (1985): Public health mycobacteriology: a guide for the level III laboratory, Atlanta, CDC.

Lampert, L.M. (1975): Modern dairy products $3^{\text {rd }} \mathrm{E}$ d. chemical publishing C.O., inc. New York.

Leite, F.; Anno, I.; Leite, S.; Roxo, E.; Morlock, G. and Cooksey, R. (2003): Isolation and identification of mycobacteria from livestock specimens and milk obtained in Brazil. Mem. Inst. Oswaldo. Cruz., 98: 319-323. 
Liebana, E.; Aranaz, A.; Mateos, A.; Vilafranca, M.; Domingo, M. and Dominguez, M. (1995): Simple and rapid detection of $M$. tuberculosis complex organisms in bovine tissue samples by PCR. J. Clin. Microbiol., 33(1): 33-36.

Lilenbaum, W.; Pessolani, M.C. and Fonseea, L.S. (2001): The use of Ag85 complex as antigen in ELISA for the diagnosis of bovine tuberculosis in dairy cows in Brazil. J. Vet. Med. B. Infect. Dis. Vet. Public Health..; 48(3): 161-166.

LoBue, P.A.; Betancourt, W.; Cowan, L.; Seli, L.; Peter, C. and Moser, K. (2004): Identification of a familial cluster of pulmonary Mycobacterium bovis disease. Int. J. Tuberc. Lung Dis., 8: 1142-46.

Ma, Y. and Barbano, D.M. (2000): Gravity separation of raw bovine milk: fat globule size distribution and fat content of milk fractions. J. Dairy Sci., 83: 1719-1727.

Mahmoud, S.F.; El- Halmouch, Y. and Montaser, M.M. (2013): Effect of probiotic bacteria on Kareish Cheese production. Life Sci. J., 10(2): 1279-1284.

Michel, A.L.; de Klerk, L.M.; Gey van Pittius, N.C.; Warren, R.M. and van Helden, P.D. (2007): Bovine tuberculosis in African buffaloes: observations regarding Mycobacterium bovis shedding into water and exposure to environmental mycobacteria, BMC Vet. Res., 27: 3-23.

Mumtaz, N.; Iqbal, Z.; Mahmood, N. and Shakoori, A.R. (2008): Reliability of PCR for Detection of Bovine Tuberculosis in Pakistan. Pakistan J. Zool., 40(5): 347-351.

Nasr, S.; Saad, N.M.; Nasr, E.A.; Wahba, N.M. and Elsherif, W.M.A. (2014): The viability of products as a cause of human tuberculosis in the UK. A review of taxonomy and culture methods, with particular reference to artisanal cheeses. Int. J. Dairy Technol., 61(4): 317- 326.

Silaigwana, B.; Green, E. and Ndip, R.N. (2012): Molecular detection and drug resistance of Mycobacterium tuberculosis complex from cattle at a dairy farm in the Nkonkobe region of South Africa: a pilot study. Int. J. Environ. Res. Public Health, 9(6): 2045-2056.

Spahr, U. and Schafroth, K. (2001): Fate of Mycobactreriun avium subsp. Paratuberculosis in Swiss hard and semihard cheese manufactured from raw milk. Appl. Environ. Microbiol., 67:4199-4205.

Thoen, C.; Lobue, P. and Kantor, I. De. (2006): The importance of Mycobacterium bovis as a zoonosis. Vet. Microbiol., 112: 339-345.

Tipu, M.Y.; Chaudhary, Z. I.; Muhammad Younus and Masood Rabbani (2012): A cross sectional study of Mycobacterium bovis in dairy cattle in and around Lahore City, Pakistan. Pak. J. Zool., 44(2): 393-398.
Mycobacterium bovis in yoghurt and kareish cheese. Glob. J. Agric. Food Safety Sci. 1(2): 261-269.

Ofukwu, R.A.; Oboegbulem, S.I. and Akwuobu, C. A. (2008): Zoonotic Mycobacterium species in fresh cow milk and fresh skimmed, unpasteurized market milk (nono) in Makurdi, Nigeria: implications for public health. J. Anim. Plant Sci., 1(1): 21-25.

Ogundeji, E.B.; Onyemelukwe, N.F.; Nwuko, A.C.; Onuoha, M.N.; Ogundeji, A.O.; Osaretin, J.E.; Eze, K.A.; Olofu, J.E.; Jik, A.W.; Kemza, S.Y. and Okafor, N.C. (2015) : Molecular detection of Mycobacterium bovis in cattle milk in Enugu State, Nigeria. Journal of Natural Sciences Research 5(12): 42-47.

Pardo, R.B.; Langoni, H.; Mendonça, L.J.P. and Chi, K.D. (2001): Isolation of Mycobacterium species in milk from cows suspected or positive to tuberculosis. Braz. J. Vet. Res. Anim. Sci. 38 (6): 284-287.

Pereira-Suarez, A.L.; Estrada-Chavez, Y.; ZunigaEstrada, A.; Lopez-Rincon, G.; Hernandez, D.U.M.; Padilla-Ramirez, F.J. and EstradaChavez, C. (2014): Detection of Mycobacterium tuberculosis complex by PCR in fresh cheese from local markets in Hidalgo, Mexico. J. Food Prot., 77(5): 849-852.

Roug, A.; Perez, A.; Mazet, J. A. K.; Clifford, D.L.; VanWormer, E.; Paul, G.; Kazwala, R. R. and Smith, W. A. (2014): Comparison of intervention methods for reducing human exposure to Mycobacterium bovis through milk in pastoralist households of Tanzania. Preventive Vet. Med., 115(3/4): 157-165.

Rowe, M.T. and Donaghy, J. (2008): Mycobacterium bovis: the importance of milk and dairy

Tucker, K.L. (2003): Does milk intake in childhood protect against later osteoporosis? Am. J. Clin. Nutr., 77(1): 10-11.

Van Brandt, L.; Coudijzer, K.; Herman, L.; Michiels, C.; Hendrickx, M. and Vlaemynck, G. (2011): Survival of M. avium ssp. paratuberculosis in yoghurt and in commercial fermented milk products containing probiotic cultures. J. App. Microbiol., 110 (5): 1252-1261.

Vestal, A.L. (1975): Procedures for the isolation and identification of mycobacteria. DHEW Publication No. (CDC); 75-8230.

Vordermeier, H.M.; Whelan, A.; Cockle, P.J.; Farrant, L.; Palmer, N. and Hewinson, R.G. (2001): Use of synthetic peptides derived from the antigens ESAT- 6 and CFP-10 for differential diagnosis of bovine tuberculosis in cattle. Clin. Diag. Lab. Immunol., 8(3): 571578.

Wahba, N.; Nasr, S.; Saad, N.; Nasr, E.A. and Elsherif, W. (2013): Detection of bovine tuberculosis in milk and serum of tuberculin reactors dairy farm animals in Assuit City, Egypt. Basic Res. J. Anim. Sci., 1: 1-6. 
Wards, L.J.; Brown, J.C. and Davey, G.P. (1995): Detection of dairy Leuconostoc strains using polymerase chain reaction. Lett. Appl. Microbiol., 20(4): 204-208.
WHO, World Health Organization (2013): Tuberculosis and gender, E-Focus: Newsletter of the WHO Global TB Programme.

\section{مدي تواجل ميكروب السل في اللبن وبعض منتجات الألبان في مدينة بني سويف، مصر \\ سعليه طلمي حسين الشنتاوي ، محد معروف على زينهم ، عداد مختار رياض ، ولاء عاثور}

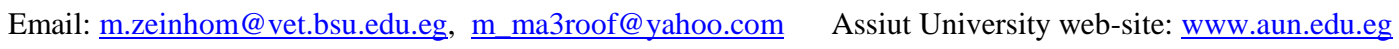

على الرغم من أن اللبن ومنتجات الألبان هي عناصر هامة في اتباع نظام غذائي صحي إلا أنه قد يمثل خطورة علي الصحة العامة إذا إلها

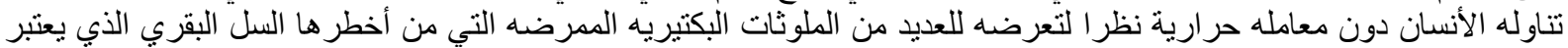

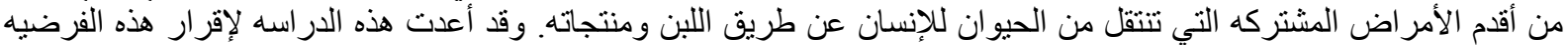

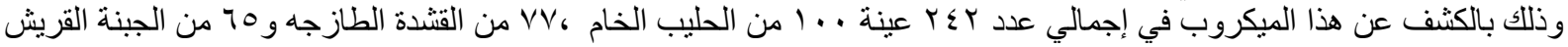

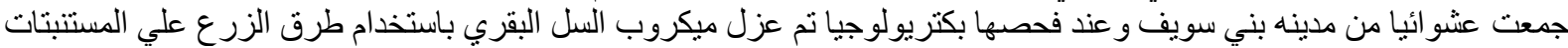

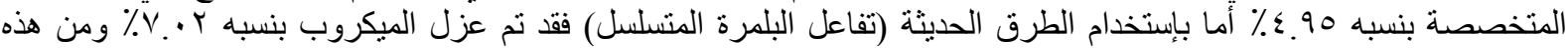

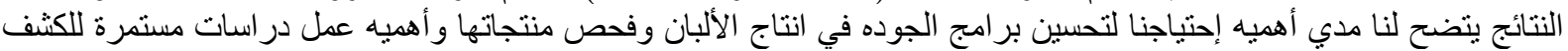

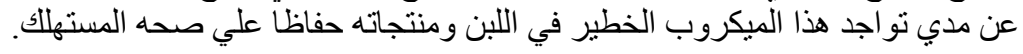

